\title{
敗血症の新しい定義とその背景
}

\section{織田 成人}

\section{要 氜}

1991 年のACCP/SCCM (American College of Chest Physicians/Society of Critical Care Medicine) の合 同カンファランスで提唱された全身性炎症反応症候群 (systemic inflammatory response syndrome : SIRS) の 概念に基づく敗血症（sepsis）の定義が，25年ぶりに改定された. 新しい敗血症の定義（Sepsis-3）では, 敗血 症を「感染に対する制御不十分な生体反応に起因する生命に危機を及ぼす臓器障害」と定義しており, 臓器障害 の評価にはSOFA（Sequential Organ Failure Assessment）スコアを用い，2点以上の上昇がある場合を敗血症 と診断する。これは従来の「重症敗血症」にあたる．そして，敗血症性ショック（septic shock）を「適切な輸 液負荷にもかかわらず，平均血圧 $\geq 65 \mathrm{mmHg}$ 維持するのに昇圧薬を必要とする，かつ血中乳酸値 $\geq 2 \mathrm{mmol} / /$ を 呈する状態」と定義した．また，ICU以外での敗血症のスクリーニングッールとしてSIRSの診断基準に代わっ て, (1)呼吸数 $\geq 22 /$ 分, (2)精神状態の変容（GCS (Glasgow Coma Scale) <15), (3)収縮期血圧 $\leq 100 \mathrm{mmHg}$ うち，2つ以上陽性の場合に敗血症を疑うqSOFA（quickSOFA）の利用を推奨している.

〔日内会誌 106：120～126，2017〕

Key words 敗血症，敗血症性ショック，臓器障害，SOFAスコア，quick SOFA

\section{はじめに}

従来，日本では，敗血症（sepsis）は「感染 症が重症化して血液中に細菌や細菌の毒素が検 出され, 全身に感染が及んだ状態」としてきた. しかし，血液培養やエンドトキシンなどの検査 結果が判明してから治療を開始したのでは予後 不良であることや，臨床的に明らかに敗血症と 考えられる症例でも, 血液中から菌や毒素が検 出されない症例が少なくないことが問題であっ た.これに対して欧米では, 1991 年にACCP (American College of Chest Physicians) とSCCM (Society of Critical Care Medicine) の合同カン ファランスで, 敗血症の早期診断, 早期治療を
目的とした新しい敗血症の定義が提案さ れた ${ }^{1)}$ 。この合同カンファランスで, 初めて 全身性炎症反応症候群 (systemic inflammatory response syndrome：SIRS）の概念が導入され, 敗血症は「感染によって引き起こされたSIRS」 と定義された. 以来，この定義は広く国際的に 認められ, 敗血症に対する研究や新しい治療 法, 各種の新規薬剤の臨床試験などのエント リークライテリアとして用いられてきた.

近年, 分子生物学的な研究手法の進歩により, 敗血症の病態生理がより詳細に明らかにされ る2)とともに, SIRSの診断基準を満たさない重症 敗血症患者が少なからず存在することが報告さ れる3)など, ACCP/SCCMの定義の問題点が指摘 
されるようになった4).このような背景を受け， 2014 年にSCCMとヨーロッパ集中治療医学会 (European Society of Intensive Care Medicine : ESICM）はタスクフォースを立ち上げ，新しい 敗血症の定義を検討してきた。そして，2016年 2月に「3回目の国際的な合意による敗血症と敗 血症性ショックの定義（Sepsis-3）」として発表 した5).この定義は, 25 年にわたって使用され てきた従来のSIRSの概念に基づく敗血症の定義 を根本的に変えるものであり, 臨床現場に及ぼ す影響は少なくないと考えられる。本稿では, 敗血症の定義の変遷と, 新しい敗血症の定義 （Sepsis-3）とその背景について概説する.

\section{1. 敗血症の定義の変遷}

1991 年に開催されたACCP/SCCMの合同カン ファランス ${ }^{1)}$ の目的の 1 つは, 敗血症の定義を統 一し，より簡便に早期に診断し, 治療できるよ うにすることであった．この合同カンファラン スで初めて導入されたSIRSの概念は，(1)体温の 異常（>38 ${ }^{\circ} \mathrm{C}$ または $\left.<36^{\circ} \mathrm{C}\right)$, (2)頻脈（>90/ 分), (3)頻呼吸 ( $>20 /$ 分または $\mathrm{PaCO}_{2}<32$ torr), (4)白血球数の異常（>12,000/ $\mathrm{mm}^{3}$ または $<$

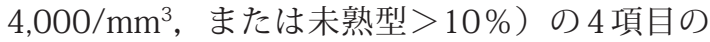
うち，2つ以上陽性の場合をSIRSとするもので あり,このSIRSが感染によって起きている場合 を「敗血症」と定義した。そして，血液中に細 菌や細菌の毒素が検出される必要はないとし た.さらにこの合同カンファランスでは, 重症 敗血症 (severe sepsis), 敗血症性ショック (septic shock）を以下のように定義した。重症敗血 症は, 敗血症の中で蔵器障害や臓器灌流低下ま たは低血圧を呈する状態であり, 臓器灌流低下 または灌流異常には, 乳酸アシドーシス, 乏尿, 意識混濁が含まれる。敗血症性ショックは, 重 症敗血症の中で, 十分な輸液負荷を行っても低 血圧が持続するものであり，その低血圧とは収 縮期血圧<90 mmHg，または通常よりも
$>40$ mmHgの低下とした. ただし, 強心薬や昇 圧薬が投与されている場合は, 低血圧でない場 合もあるとしている.

この感染によって引き起こされたSIRSを敗血 症とする定義は, 当初はあまりに感度が高く, 特異度が低いことが問題とされた。 しかし, 敗 血症患者のスクリーニングッールとしては有用 であり，敗血症の早期診断，早期治療を進める うえでは有用と考えられるようになり，その 後, 世界中で広く受け入れられるようになった。

1991 年の合同カンファランスから 10年を経 た 2001 年に, 敗血症の定義を再検討する国際 カンファランスがSCCM, ESICM, ACCPをはじ めとする5つの学会のエキスパートが参加して 開催された6). このカンファランスでは, これ まで使用されてきたSIRSの概念はある程度妥当 であるが，敗血症診断のためにはあまりに特異 度が低いことが問題とされた。 そこで, 従来の SIRSの診断基準に, 明らかな浮腫や体液過剩, 糖尿病ではない患者における高血糖の持続, CRP（C-reactive protein）やプロカルシトニン (procalcitonin：PCT）の上昇などの全身所見や 検査值を加え, さらに呼吸不全やビリルビンの 上昇, 凝固異常など, いくつかの藏器障害の指 標を追加し, 感染が疑われる患者でこれらの症 状や検查值異常のうち, いくつか（具体的に何 項目とは決められていない）が認められれば敗 血症と診断することを提案した。しかし, この 提案はあまりに煩雑かつ曖昧すぎたために, 広 く受け入れられるには至らなかった。

\section{2. 改訂の背景}

1991年に初めて定義が統一されたことで, こ の定義のもとで敗血症に関する様々な臨床研究 が行われるようになった。 そして2000年代に 入ると, これらの臨床研究によって, 敗血症に 有効な治療法が報告されるようになった。例え ば, 2001年に初めての敗血症治療薬としてFDA 
(Food and Drug Administration)の認可を取得し たリコンビナントヒト活性化プロテインC (recombinant human activated protein $\mathrm{C}$ : rhAPC）や，重症患者の血糖值を厳密に管理す るintensive insulin therapy (IIT), 敗血症診断後 6 時間以内に目標とする指標を達成する循環管 理 (early goal-directed therapy：EGDT), 敗血症 性ショックに対する低用量ステロイド療法など である。これらのエビデンスをもとに，2004年 に初めての敗血症診療ガイドラインであるSurviving Sepsis Campaign Guidelines（SSCG）が発 表され7)，広く臨床で使われるようになった。 その後, SSCGは2回改訂されているが, 日本で は日本集中治療医学会が，2012年 11 月に「日 本版敗血症診療ガイドライン」を発表した ${ }^{8)}$. これらのガイドラインはいずれも臓器障害を発 症した重症敗血症や敗血症性ショックを対象と したものであり，単にSIRS基準を満たすだけの 敗血症は対象としていない.

これらと並行して, 分子生物学的な手法の導 入によって, 敗血症の病態生理の研究において も新たな進展がみられた ${ }^{2)}$. 生体は病原微生物 の侵入を, 自然免疫を担当するマクロファージ や樹状細胞の表面に存在するToll-like receptors （TLRs）などのパターン認識受容体（pattern recognition receptors：PRRs）で感知する. 例え ば，グラム陰性菌の毒素であるエンドトキシン はTLR-4で認識される。エンドトキシンのよう なPRRsで認識される物質をpathogen-associated molecular patterns (PAMPs) と呼んでいる. PAMPsがPRRsで認識されると, 細胞内のシグナ ル伝達経路が活性化され, 細胞間伝達物質であ るサイトカインが産生される. TNF（tumor necrosis factor) $-\alpha$ やL (interleukin)-1 $\beta$ な゙の炎 症性サイトカイン（pro-inflammatory cytokine） は，他の免疫担当細胞を刺激してIL-6 やIL-8な どのサイトカインを誘導する。これらのサイト カインによって好中球や補体系が活性化され, 感染局所への好中球の遊走や活性化を促し, 病
原微生物を排除すべく作用する。これら一連の 自然免疫を中心とした反応は, 生体が病原微生 物を排除するために不可欠な反応である。しか し, これらの反応が過剩になると, 産生された サイトカインが血中へ流入し, 肝での急性相蛋 白の産生, 凝固系の活性化などが起こり, 発熱 や頻脈, 頻呼吸, 白血球増多などの全身性炎症 反応を引き起こす。これがSIRSであり，SIRSの 本態は血中で炎症性サイトカインが高值となる 「高サイトカイン血症」と考えられている．通 常, SIRSは抗炎症性サイトカインや受容体拮抗 物質などの産生により，次第に終息に向かう が，最初の侵襲が過大であったり侵襲が持続し たりすると，様々な液性因子（メディエータ） が体内で産生され，血管作動性メディエータや 微小血栓による臓器灌流異常や血管内皮傷害, 浮腫, さらには重要臟器の細胞傷害を引き起こ し, ショックや多臓器不全へと進展する.

従来, 敗血症では, PAMPsが自然免疫を活性 化すると考えられていたが，近年は好中球が細 菌を捕捉する仕組みであるNETs（neutrophil extracellular traps）の構成成分であるヒストン やHMGB1 (high mobility group box 1) などの, 体内で産生されるDAMPs (danger-associated molecular patterns）あるいはalarminsと呼ばれ る物質も, PRRsに結合し, 自然免疫を活性化す ることが明らかになった。

一方で，過剩な炎症を制御すべく産生される 抗炎症性サイトカインが優位になる（代償性抗 炎症反応症候群 (compensated anti-inflammatory response syndrome : CARS)）と, 逆に免疫が抑 制されて免疫麻痺（immunoparalysis）と呼ばれ る状態に陥り, 新たな感染症の発症や感染が持 続することにより臓器障害を発症し, 転帰不良 となることが明らかになった。最近は, SIRSよ りもこの免疫麻痺が敗血症の転帰を左右する重 要な病態であることが認識されるようになっ た.これらのことから，自然免疫の活性化によ る炎症反応を, 発熱や頻脈, 頻呼吸, 白血球増 
表 1 敗血症の新しい定義と診断基準（文献5より（日本語訳は著者））

\begin{tabular}{|c|c|c|}
\hline 病態分類 & 定義 & 診断基準 \\
\hline $\begin{array}{l}\text { 敗血症 } \\
\text { sepsis }\end{array}$ & $\begin{array}{l}\text { 感染に対する制御不十分な生体反応に起因する, } \\
\text { 生命に危機を及ぼす臓器障害 }\end{array}$ & SOFAスコアの合計で 2 ポイント以上の上昇 \\
\hline $\begin{array}{l}\text { 敗血症性ショック } \\
\text { septic shock }\end{array}$ & $\begin{array}{l}\text { 敗血症のサブセットで, 循環や細胞機能, 代謝の } \\
\text { 異常により死亡率を増加させるに足る状態 }\end{array}$ & $\begin{array}{l}\text { 適切な輸液負荷にも拘らず平均血圧 } \geq 65 \mathrm{mmHg} \\
\text { を維持するのに昇圧薬が必要，かつ血中乳酸値 } \\
\geq 2 \mathrm{mmol} / / \text { 呈する状態 }\end{array}$ \\
\hline
\end{tabular}

SOFA : Sequential Organ Failure Assessment

多の単純な臨床所見のみでとらえようとする SIRSの診断基準では, 複雑な敗血症の病態を的 確に診断するには不十分であり, 敗血症の定義 を見直すべき時期に来ているとする論文が，こ の領域のエキスパートたちにより発表された4).

一方, 臨床面でも, SIRSの診断基準を満たし ただけの感染症患者を, 本来は感染が重篤化し て生命に危機を及ぼすような患者に使われてい た敗血症という名称で呼ぶことへの疑問も以前 から呈されていた。 つまり，インフルエンザの 患者でもSIRSの診断基準を満たせば敗血症にカ ウントされることが問題であるとされた。さら に最近, オーストラリアとニュージーランドで 行われたICU（intensive care unit）患者を対象と した大規模観察研究3)で, 臓器障害を発症した 感染症患者のうち，12.1\%がSIRSの診断基準を 満たしていないことが明らかになった。つま り, SIRSの診断基準に従うと, 重症敗血症の 8 人に 1 人は敗血症と診断されないことになる. さらに,これらSIRSでない患者の死亡率は, SIRS の診断基準を満たす患者とほぼ同等であった。 これらの問題点が指摘されたことを背景に, SCCMとESICMは 2014 年にタスクフォースを立 ち上げ,新しい敗血症の定義の検討を開始した。

\section{3. 新しい敗血症の定義}

2016 年 2 月にJAMAに発表された新しい敗血 症の定義(5) は, Sepsis-3 と銘打たれている.これ は1991年1), 2001年6)の合同カンファランスに
次いで 3 回目の改定であることを示している. この論文では, 敗血症の基本概念を以下のよう に述べている.

・敗血症は感染による死亡の主な原因であ り, 認識が遅れたり治療が遅れたりすると転帰 不良となるため，その認識は急を要する.

・敗血症は病原体の要素とともに生体の要素 (例えば, 性別, 人種, 遺伝的素因, 年齢, 併存 症, 環境など）に影響される症候群である. 単 なる感染症と敗血症を区別するのは，急激なあ るいは制御できない生体反応と臓器障害の存在 である。

・敗血症に起因する臓器障害は，時には明ら かでないことがある。 それ故, 感染のある患者 では常にその存在を考慮すべきである，逆に， 新しく起きた臓器障害が認識されていない感染 による場合もある，説明のつかない臓器障害で は常に感染が隠れていないか疑う必要がある.

・敗血症の臨床的, 生物学的な所見は, 事前 に存在する急性疾患や長期にわたる併存疾患, 薬物療法や治療によって修飾され得る.

・特異な感染症では, 制御できない全身的な 生体反応を示さずに，局所の臓器障害を呈する ことがある。

そして，敗血症を「感染に対する制御不十分 な生体反応に起因する生命に危機を及ぼす臓器 障害」と定義した（表 1).

また，一般市民向けの定義として「感染に対 する体の反応が, 自らの組織や臓器を傷害する ことで生じる生命に関わる状態」としている. 
表2 SOFA（Sequential Organ Failure Assessment）スコア ${ }^{9)}$

\begin{tabular}{|c|c|c|c|c|c|}
\hline 臓器システム & $\begin{array}{c}\text { スコア } \\
0\end{array}$ & 1 & 2 & 3 & 4 \\
\hline $\begin{array}{l}\text { 呼吸 } \\
\mathrm{PaO}_{2} / \mathrm{F}_{1} \mathrm{O}_{2}\end{array}$ & $\geq 400$ & $<400$ & $<300$ & $\begin{array}{l}<200 \\
+ \text { +人工呼吸 }\end{array}$ & $\begin{array}{l}<100 \\
+ \text { 人工呼吸 }\end{array}$ \\
\hline $\begin{array}{l}\text { 凝固 } \\
\text { 血小板数 }\left(\times 10^{3} / \mu \mathrm{l}\right)\end{array}$ & $\geq 150$ & $<150$ & $<100$ & $<50$ & $<20$ \\
\hline $\begin{array}{l}\text { 肝 } \\
\text { 総ビリルビン }(\mathrm{mg} / \mathrm{dl}) \text { ) }\end{array}$ & $<1.2$ & $1.2 \sim 1.9$ & $2.0 \sim 5.9$ & $6.0 \sim 11.9$ & $>12.0$ \\
\hline $\begin{array}{l}\text { 心血管 } \\
\text { 平均血圧 (MAP) } \\
\text { カテコラミン }\end{array}$ & $M A P \geq 70$ & MAP $<70$ & $\begin{array}{l}\text { ドパミン<5 } \\
\text { or ドブタミン }\end{array}$ & $\begin{array}{l}\text { ドパミン } 5.1 〜 15 \\
\text { or エピネフリン } \\
\text { or ノルエ } 0.1 \\
\text { ノr ピネリン } \leq 0.1\end{array}$ & $\begin{array}{l}\text { ドパミン>15 } \\
\text { or エピネフリン>0.1 } \\
\text { or ノルエピネフリン>0.1 }\end{array}$ \\
\hline $\begin{array}{l}\text { 中枢神経 } \\
\text { GCS }\end{array}$ & 15 & $13 \sim 14$ & $10 \sim 12$ & $6 \sim 9$ & $<6$ \\
\hline $\begin{array}{l}\text { 腎 } \\
\text { クレアチニン }(\mathrm{mg} / \mathrm{dl}) \\
\text { 尿量 (ml/day) }\end{array}$ & $<1.2$ & $1.2 \sim 1.9$ & $2.0 \sim 3.4$ & $\begin{array}{l}3.5 \sim 4.9 \\
<500\end{array}$ & $\begin{array}{l}>5.0 \\
<200\end{array}$ \\
\hline
\end{tabular}

GCS : Glasgow Coma Scale

そして, 敗血症の診断には, SOFA (Sequential Organ Failure Assessment）スコア（表2）を用 いて臓器障害を評価し，SOFAスコアの合計が 2 点以上変化した場合に敗血症と診断するとして いる. SOFAスコアは 1996 年にESICMが提案し た多臓器不全の評価法9)であり, 最初に提案さ れたときはSepsis-related Organ Failure Assessment scoreという名称であった。 その後, 名称 がSequential Organ Failure Assessment scoreに 変更され10), 現在ではICUにおける重症度評価 法として広く世界的に用いられている。

敗血症性ショックは,「敗血症のサブセット で，循環や細胞機能，代謝の異常により死亡率 を増加させるに足る状態」と定義された。 そし て, 診断基準として「適切な輸液負荷にもかか わらず，平均血圧 $\geq 65 \mathrm{mmHg}$ 維持するのに昇 圧薬を必要とする，かつ血中乳酸值 $\geq 2 \mathrm{mmol} / 1$ を呈する状態」としている. そして, この定義に 従うと, 院内死亡率は40\%以上であるとしている.

ICUではSOFAスコアが日常的に用いられてい るが，一般病棟や一般診療科の外来などではな じみが薄い. 何よりもSOFAスコアを評価するに は，検査やモニタリングが必要である。そこで,
ICU以外の場所で敗血症をスクリーニングする ためのツールとして, quickSOFA (qSOFA) が提 案された. qSOFAは, (1)呼吸数 $\geq 22$ /分, (2)精神 状態の変容 $(\mathrm{GCS}<15)$, (3) 収縮期血圧 $\leq$ $100 \mathrm{mmHg}$ のち，2つ以上を満たす場合に陽 性とするものである。 qSOFAが陽性の場合, 各 種検査を行ってSOFAスコアを評価するように 推奨している.このスコアは, 7 万人以上の入 院患者を対象とした解析から導き出されたもの で, SIRSの診断基準よりも簡便で, 感度・特異 度ともにSIRSよりも高いことが統計学的に示さ れている。

以上，新しい敗血症の定義のポイントをこれ までのSIRSをもとにした敗血症の定義と比較し てまとめると,

1. SIRSは敗血症の診断基準から削除された.

2. 敗血症は臓器障害を伴った場合に限定され た（従来の重症敗血症）.

3. 臓器障害の評価にSOFAスコアが導入された。

4. 敗血症性ショックの診断基準に, 血中乳酸 值の異常が追加された。

5. ICU以外での敗血症のスクリーニングに, qSOFAが導入された. 


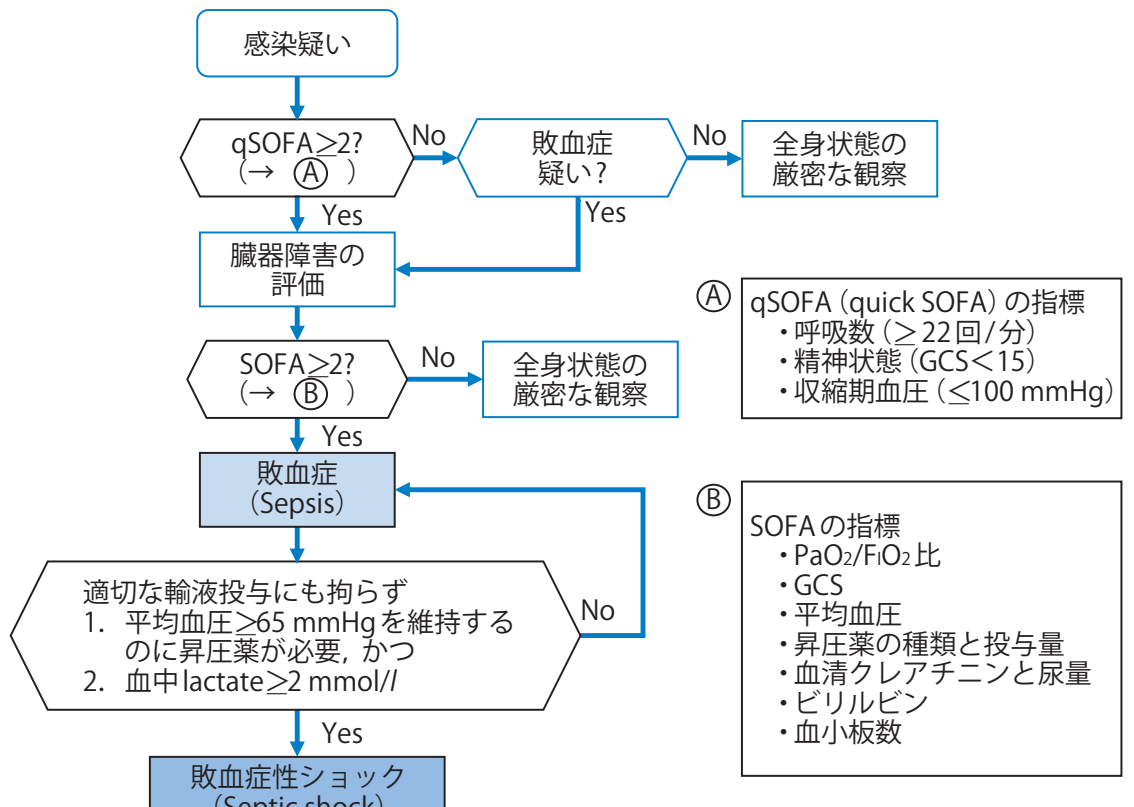

(Septic shock)

図 敗血症および敗血症性ショック診断のためのフローチャート

(文献5より（日本語訳は著者）

ということになる.

図は，新しい定義に則った敗血症および敗血 症性ショックの診断フローチャートである．感 染症患者あるいは感染症が疑われる患者では, まず呼吸数, 意識レベル (GCSで評価), 血圧を 測定し，qSOFAを評価する。そして，2項目以上 陽性の場合，敗血症を疑い，SOFAスコアを評価 する. SOFAスコアの合計が2点以上上昇した場 合，敗血症と診断する。そして，輸液負荷を開 始する.十分な輸液負荷を行っても血圧が上昇 せず, 平均血圧 $65 \mathrm{mmHg}$ 以上を維持するのにノ ルアドレナリンなどの昇圧薬投与を必要とする 場合，血中乳酸值を測定する. 血中乳酸值が 2 $\mathrm{mmol} / 1$ 以上を示す場合は敗血症性ショックと 診断する. 敗血症, 敗血症性ショックと診断さ れた場合は，直ちに初期治療を行いながらICU へ入室させ，ガイドラインに基づいた治療を開 始する.

\section{おわりに}

新しい敗血症の定義, Sepsis-3について, こ れまでの敗血症の定義の変遷と改定された理由 を含めて解説した. 今回の改定は, 25 年間使わ れてきた従来の定義を大幅に変更するものであ り, 臨床現場での混乱が予想される. 特に敗血 症の診断基準であるSOFAスコアになじみの薄 いICU以外の現場では, qSOFAとSOFAスコアの 普及が喫緊の課題である. 現在, 欧米のガイド ラインであるSSCGの 4 回目の改訂が行われてお り, 恐らく2017年早々に発表される予定になつ ている，同時に，日本版敗血症診療ガイドライ ンの改訂作業が, 日本集中治療医学会と日本救 急医学会の合同委員会で進められており, こち らも近々公表される予定になっている。ぜひ， 新しい敗血症の定義を臨床に積極的に取り入れ るとともに, 新しい敗血症診療ガイドラインに も注目していただきたい. 
著者のCOI（conflicts of interest）開示：織田成人；講演 料 (MSD，大正富山医薬品，ファイザー)，研究費・助 成金（旭化成ファーマ)，寄附金（アステラス製薬，大 正富山医薬品，大日本住友製薬，鳥居薬品，日本血液製 凨機構，ファイザー)

\section{文献}

1) Members of the American College of Chest Physicians/Society of Critical Care Medicine Consensus Conference Committee : American College of Chest Physicians/Society of Critical Care Medicine Consensus Conference : Definitions for sepsis and organ failure and guidelines for the use of innovative therapies in sepsis. Crit Care Med $20: 864-874,1992$.

2) Angus DC, van der Poll T : Severe sepsis and septic shock. N Engl J Med 369 : 840-851, 2013.

3) Kaukonen KM, et al : Systemic inflammatory response syndrome criteria in defining severe sepsis. N Engl J Med 372: 1629-1638, 2015 .

4) Vincent JL, et al : Sepsis definitions : time for change. Lancet $381: 774-775,2013$.

5) Singer $\mathrm{M}$, et al : The third international consensus definitions for sepsis and septic shock(Sepsis-3). JAMA 315 : 801-810, 2016.

6) Levy MM, et al : 2001 SCCM/ESICM/ACCP/ATS/SIS International Sepsis Definitions Conference. Crit Care Med $31: 1250-1256,2003$.

7) Dellinger RP, et al : Surviving Sepsis Campaign Guidelines for management of severe sepsis and septic shock. Crit Care Med 32 : 858-873, 2004.

8）日本集中治療医学会Sepsis Registry委員会：日本版敗血症診療ガイドライン。 日集中医誌 20:124-173, 2013.

9) Vincent JL, et al : The SOFA (Sepsis-related Organ Failure Assessment) score to describe organ dysfunction/ failure. Intensive Care Med 22 : 707-710, 1996.

10) Vincent JL, et al : Use of the SOFA score to assess the incidence of organ dysfunction/failure in intensive care units : results of a multicenter, prospective study. Crit Care Med 26 : 1793-1800, 1998. 